\title{
Transcriptional activation of heat shock protein 27 gene expression by $17 \beta$-estradiol and modulation by antiestrogens and aryl hydrocarbon receptor agonists
}

\section{W Porter, F Wang, R Duan, C Qin, E Castro-Rivera, K Kim and S Safe}

Department of Veterinary Physiology and Pharmacology, Texas A\&M University, College Station, Texas 77843-4466, USA

(Requests for offprints should be addressed to S H Safe, Department of Veterinary Physiology and Pharmacology, Texas A\&M University, TAMU 4466, College Station, Texas 77843-4466, USA; Email:ssafe@cvm.tamu.edu)

\begin{abstract}
Heat shock protein 27 (Hsp 27) is expressed in mammary tumors and may play a role in tumor growth and response to anti-neoplastic drug therapy. $17 \beta$-Estradiol $\left(\mathrm{E}_{2}\right)$ induces Hsp 27 mRNA levels in MCF-7 human breast cancer cells, and we have investigated the comparative inhibitory mechanisms using the aryl hydrocarbon receptor (AhR) agonist, 2,3,7,8-tetrachlorodibenzo- $p$-dioxin (TCDD) and the direct-acting antiestrogen ICI 164,384. TCDD inhibited $\mathrm{E}_{2}$-induced Hsp 27 gene expression and analysis of the Hsp 27 gene
\end{abstract}

promoter showed that the inhibitory response was associated with $\mathrm{AhR}$ interactions with a pentanucleotide motif at -3 to +2 in the promoter that corresponded to the core sequence of a dioxin responsive element. In contrast, ICI 164,384 induced Hsp 27 gene expression and reporter gene activity in MCF-7 cells and this represents one of the few examples of the estrogen receptor- $\alpha(E R \alpha)$ agonist activity of the 'pure' antiestrogen ICI 164,384 .

Fournal of Molecular Endocrinology (2001) 26, 31-42

\section{INTRODUCTION}

High and low molecular weight heat shock proteins (Hsps) have been widely identified in mammalian and non-mammalian cells/tissues and play an important role in maintaining cellular homeostasis and responding to extracellular stimuli (Lindquist \& Craig 1988, Ciocca et al. 1993, Jakob \& Buchner 1994, Smith et al. 1998). Hsp 27 is a low molecular weight member of the Hsp family and different phosphorylated forms have been widely identified and linked to the biological activity of this protein (Ciocca et al. 1993). Hsp 27 is induced in many cell types in response to stress and there is evidence that this protein may play a role in multiple cellular processes. For example, in murine embryonic stem cells, Hsp 27 prevents differentiating cells from undergoing apoptosis (Ciocca et al. 1993) and studies in other cell lines also show that Hsp 27 blocks apoptotic pathways (Ciocca et al. 1993,
Mehlen et al. 1996, 1997, Guenal et al. 1997, Wagstaff et al. 1999).

Hsp 27 is highly expressed in many tumors and cancer cell lines including estrogen receptor (ER)positive MCF-7 human breast cancer cells and the biological significance and prognostic value of $\mathrm{Hsp}$ 27 in mammary tumors has been reported (Ciocca et al. 1983, Tetu et al. 1992, Oesterreich et al. 1993, 1996b, Langdon et al. 1995, Munoz de Toro \& Luque 1997, Hsu \& Hsu 1998, Arts et al. 1999). In MCF-7 cells stably transfected with human Hsp 27 antisense cDNA, decreased Hsp 27 expression was associated with growth inhibition and cellular hypertrophy (Mairesse et al. 1996). In contrast, induction of Hsp 27 in MCF-7 and other cancer cell lines is associated with increased cell growth and resistance to cytotoxic drugs such as doxorubicin (Oesterreich et al. 1993). Early studies showed a correlation with Hsp 27 and ER expression in breast cancer cells (Adams \& McGuire 1985, Horne et al. 
1988, Ciocca et al. 1990); however, the utility of Hsp 27 protein levels as a prognostic factor for breast cancer is complex. Oesterreich and co-workers showed that immunostained Hsp 27 protein levels in axillary lymph node-negative breast cancer patients did not correlate with disease-free survival or overall survival even though there was a positive correlation with ER status (Oesterreich et al. 1996b).

Hsp 27 is induced by heat shock and $17 \beta-\mathrm{E}_{2}$ in breast cancer cells (Edwards et al. 1980, 1981, Moretti-Rojas et al. 1988, Fuqua et al. 1989, Dunn et al. 1993). Oesterreich and co-workers initially identified estrogen response element (ERE) halfsites, Sp1 and AP-2 binding sites in the $\mathrm{E}_{2}$ responsive proximal region of the $\mathrm{Hsp} 27$ gene promoter (Oesterreich et al. 1996a). They also identified a nuclear matrix protein (HET) that inhibits expression of constructs containing Hsp 27 gene promoter inserts (Oesterreich et al. 1997). Studies in this laboratory identified an Sp1 $(\mathrm{N})_{10}$ ERE half-site motif (Porter et al. 1996) that bound $\mathrm{ER} \alpha$ and $\mathrm{Sp} 1$ proteins and in transient transfection assays this region of the Hsp 27 gene promoter was $\mathrm{E}_{2}$-responsive. However, subsequent studies showed that only the GC-rich site (Porter et al. 1997) was required for $\mathrm{E}_{2}$-mediated transactivation that involved $\mathrm{ER} \alpha / \mathrm{Sp} 1$ binding to the GC-rich site in which ER $\alpha$ bound Sp1 protein but not DNA. This ERE-independent pathway for ER $\alpha$ action in breast cancer cells was subsequently characterized in promoters of the c-fos, adenosine deaminase, cathepsin $\mathrm{D}$, insulin-like growth factor binding protein $4, \mathrm{E} 2 \mathrm{~F} 1$ and $b c l-2$ genes (Porter et al. 1997, Duan et al. 1998, Sun et al. 1998, Wang et al. 1998, 1999, Dong et al. 1999, Qin et al. 1999, Xie et al. 1999).

Although the precise role of Hsp 27 in breast cancer is unclear, overexpression of this gene is associated with resistance to some cytotoxic drugs. Therefore, this study was initiated to investigate inhibition of $\mathrm{E}_{2}$-induced Hsp 27 gene expression by direct-acting antiestrogens such as ICI 164,384 and aryl hydrocarbon receptor (AhR) agonists through inhibitory AhR-ER $\alpha$ cross-talk. The $\mathrm{AhR}$ is a ligand-activated basic helix-loop-helix protein that forms a nuclear heterodimer with the AhR nuclear translocator (Arnt) protein and induces gene expression through interaction with dioxin responsive elements (DREs) in target gene promoters (Swanson \& Bradfield 1993, Whitlock 1993, Whitlock et al. 1996). It has been shown that AhR agonists inhibit $\mathrm{E}_{2}$-induced responses in the rodent uterus and mammary tumors and in human breast cancer cell lines (reviewed in Safe 1995 and Safe et al. 1999), and inhibitory DREs (iDRE) have been identified as genomic targets in promoter regions of the $\mathrm{E}_{2}$-responsive cathepsin $\mathrm{D}, \mathrm{pS} 2$ and $\mathrm{c}$-fos genes (Krishnan et al. 1995, Duan et al. 1999, Gillesby et al. 1997). The results of this study show that, like several other $\mathrm{E}_{2}$-induced genes, $\mathrm{AhR}$ agonists block induction of Hsp 27 by interaction with an iDRE in the promoter, whereas ICI 164,384 exhibits $\mathrm{ER} \alpha$ agonist activity and this is one of the few examples showing that a 'pure' antiestrogen exhibits estrogenic activity.

\section{MATERIALS AND METHODS}

\section{Cells, chemicals and biochemicals}

MCF-7 cells were obtained from the American Type Culture Collection (ATCC, Manassas, VA, USA). Ah-nonresponsive benzo[a]pyrene-resistant MCF-7 cells (MCF-7 ${ }^{\mathrm{BaPr}}$ ) were derived in this laboratory as previously described (Moore et al. 1994). Cells were maintained in MEM medium with phenol red and supplemented with $10 \%$ fetal bovine serum plus $10 \mathrm{ml}$ antibiotic-antimyotic solution (Sigma Chemical Co., St Louis, MO, USA) in an air-carbon dioxide (95:5) atmosphere at $37^{\circ} \mathrm{C}$. Prior to their use in this study, MCF $-7^{\mathrm{BaPr}}$ were maintained in $1 \mu \mathrm{M}$ benzo[a]pyrene for several passages to ensure their Ah-nonresponsiveness as previously described (Moore et al. 1994). Cells were grown in DME-F/12 medium without phenol red and $2.5 \%$ dextran/charcoal-stripped fetal bovine serum 2 days before dosing. The human ER $\alpha$ $(\mathrm{hER} \alpha)$ expression plasmid (HEG0) was kindly provided by Dr Ming-Jer Tsai (Baylor College of Medicine, Houston, TX, USA), and the variant $\mathrm{ER} \alpha$ constructs HE11 (DNA binding domain deficient), HE15 (expressing AF1) and HE19 (expressing AF2) were provided by Professor Chambon (Illkirch, France) and ER-AF1 containing mutations in AF2 (D538A, E542A, D545A) was provided by Dr Donald McDonnell, Duke University (Durham, NC, USA). ICI 164,384 and 182,780 were obtained from Dr Alan Wakeling (Astra Zeneca, Macclesfield, UK), tamoxifen and 4'-hydroxytamoxifen were purchased from Sigma Chemical Co. TCDD was synthesized in this laboratory and was $>99 \%$ pure as determined by gas chromatography. Oligonucleotides were synthesized by the Gene Technologies Laboratory, Texas A\&M University (College Station, TX, USA). Human AhR antibodies were kindly provided by Dr Carol Holtzapple (USDA Laboratory, College Station, TX, USA). All other chemicals and biochemicals were the highest quality available from commercial sources. 


\section{Oligonucleotides and plasmids}

The oligonucleotides used in this study are summarized below.

DRE:

5'-GATCTCCGGTCCTTCTCACGCAACGC

C'TGGGG-3'

mutant DRE:

5'-GATCTCCGGTCCTTCTACATCAACGC

CTGGGG-3' (mutant iDRE underlined)

For construction of the pHsp27 plasmid, the following two primers were used.

A (sense strand):

5'-GGAAGCTTGGAGGGGCGGCC-3'

$B$ (antisense):

5'-GGTCTAGATCAGAAAAGTGCGGGGC-3'

For construction of pHsp27.m1 plasmid, the previous antisense primer was replaced by a primer with a mutation in the core DRE sequence (the mutation is underlined).

5'-GGTCTAGATCAGAAAAGTTCTGGGC-3'

The PCR condition was $94{ }^{\circ} \mathrm{C}$ for $\overline{3} \min , 94^{\circ} \mathrm{C}$ for $30 \mathrm{~s}, 55^{\circ} \mathrm{C}$ for $30 \mathrm{~s}$, and $72{ }^{\circ} \mathrm{C}$ for $1 \mathrm{~min}$ for 30 cycles and $72{ }^{\circ} \mathrm{C}$ for $5 \mathrm{~min}$. The high-fidelity DNA polymerase, Finnzymes Oy from MJ Research, Inc. (Watertown, MA, USA), was used in the PCR reaction. The resultant $\mathrm{PCR}$ product was cut with HindIII and XbaI at $37^{\circ} \mathrm{C}$ overnight and ligated into pBLCAT3 vector (ATCC). The ligation product was transformed into DH5 $\alpha$ competent Escherichia coli cells and confirmed by restriction enzyme mapping and DNA sequencing using Sequitherm cycle sequencing kit from Epicentre Technologies (Madison, WI, USA). pERE ${ }_{3}$ contained three consensus ERE motifs (GGTCA nnn TGACC) separated by ten nucleotides cloned into pBLTATACAT as described (Saville et al. 2000).

\section{Northern analysis}

The plasmid pUCHS208 containing the Hsp 27 cDNA was purchased from StressGen (Victoria, British Columbia, Canada). The plasmid containing the $\beta$-tubulin gene was obtained from ATCC. RNA was extracted from cells treated with the appropriate chemicals by using the acidic guanidinium thiocyanate procedure followed by electrophoresis on a $1 \cdot 2 \%$ formaldehyde agarose gel and transferred to a nylon membrane. The membrane was then exposed to u.v. light for $5 \mathrm{~min}$ to cross-link RNA to the membrane and baked at $80{ }^{\circ} \mathrm{C}$ for $2 \mathrm{~h}$. The membrane prepared in this manner was prehybridized in a solution containing $0 \cdot 1 \%$ BSA, $0 \cdot 1 \%$ Ficoll, $0 \cdot 1 \%$ polyvinylpyrollidone, $10 \%$ dextran sulfate, $1 \% \mathrm{SDS}$ and $5 \times \mathrm{SSPE}(0.75 \mathrm{M}$ sodium chloride, $50 \mathrm{nM}$ sodium dihydrogen phosphate, $5 \mathrm{mM}$ EDTA) for $18-24 \mathrm{~h}$ at $65{ }^{\circ} \mathrm{C}$ and hybridized in the same buffer for $24 \mathrm{~h}$ with the ${ }^{32} \mathrm{P}$-labeled DNA probe $\left(10^{6}\right.$ c.p.m. $\left./ \mathrm{ml}\right)$. The cDNA probes were labeled with $\left[\alpha-{ }^{32} \mathrm{P}\right] \mathrm{CTP}$ using the random primed DNA labeling kit (Boehringer-Mannheim, Indianapolis, IN, USA). The resulting blots were quantitated using a Betagen Betascope 603 blot analyzer (Intelligenetics, Mountain View, CA, USA) and visualized by autoradiography using X-Omat film (Eastman Kodak Co., Rochester, NY, USA). Hsp 27 mRNA levels were standardized against $\beta$-tubulin mRNA.

\section{Transient transfection assay}

Cultured wild-type $\mathrm{MCF}-7$ or variant $\mathrm{MCF}-7^{\mathrm{BaPr}}$ cells were transfected by the calcium phosphate method with $10 \mu \mathrm{g}$ of the appropriate pHsp27 construct plus hER, HE11, HE15, ER-AF1 and HE19 expression plasmid $(10 \mu \mathrm{g})$ using $100 \times 20 \mathrm{~mm}$ Falcon culture dishes. Preliminary concentration-dependent studies were carried out using both $\mathrm{E}_{2}$, antiestrogens and TCDD to determine effective concentrations for induction and inhibitory responses; the concentrations were $10 \mathrm{nM} \mathrm{E} \mathrm{E}_{2}, 10 \mathrm{nM} \mathrm{TCDD}$ and $1 \mu \mathrm{M}$ concentration for the antiestrogens. After $18 \mathrm{~h}$, the media was changed and the cells were treated with the appropriate chemicals in DMSO for $44 \mathrm{~h}$. Cells were then washed with PBS and scraped from the plates. Cell lysates were prepared in $0.16 \mathrm{ml}$ of $0.25 \mathrm{M}$ Tris- $\mathrm{HCl}, \mathrm{pH} 7 \cdot 5$, by three freeze-thawsonication cycles ( $3 \mathrm{~min}$ each). Cell lysates were incubated at $56{ }^{\circ} \mathrm{C}$ for $7 \mathrm{~min}$ to remove endogenous deacetylase activity. Chloramphenicol acetyl transferase (CAT) activity was determined using $\quad 0 \cdot 2 \quad \mathrm{mCi}$ d-threo-[dichloroacetyl-1- ${ }^{14} \mathrm{C}$ ] chloramphenicol and $4 \mathrm{mM}$ acetyl-CoA as substrates. The protein concentrations were determined using BSA as a standard. Following TLC, acetylated products were visualized and quantitated using a Betascope 603 Blot analyzer. For most experiments, cells were cotransfected with pCDNA3 $1 /$ His/LacZ plasmid (Invitrogen, Carlsbad, CA, USA) and $\beta$-galactosidase activity was determined and used to correct for transfection efficiency. Band intensities were also quantitated by densitometry using the Molecular Dynamics Zero-D software package (Molecular Dynamics, Sunnyvale, CA, USA) and a Sharp JX-330 scanner (Mahwah, NJ, USA). CAT activity was calculated as the percentage of that observed in cells treated with DMSO alone and results are expressed as means \pm S.D.s. The experiments were carried out at least in triplicate. 


\section{u.v.-DNA cross-linking}

For cross-linking studies, $10 \mathrm{pmol}$ of the synthetic oligonucleotide (Hsp 27-DRE) was annealed to 10 pmol of a cross-linked primer sequence. The annealed template was end-filled with the Klenow fragment of DNA polymerase in the presence of $0 \cdot 1 \mu \mathrm{M}$ dGTP, dATP and bromodeoxyuridine (BrdU) and $1 \mathrm{mM}\left[{ }^{32} \mathrm{P}\right] \mathrm{dCTP}$ as previously described (Krishnan et al. 1995, Gillesby et al. 1997) and was designated the BrdU-substituted DRE oligonucleotide. Nuclear extracts $(10 \mu \mathrm{g})$ from MCF-7 cells treated with appropriate chemicals were incubated with the BrdU-DRE for $15 \mathrm{~min}$ at $20{ }^{\circ} \mathrm{C}$ following a 15 -min incubation at $20^{\circ} \mathrm{C}$ with $400 \mathrm{ng}$ of poly $(\mathrm{dI}-\mathrm{dC})$ in HEGD buffer $(25 \mathrm{nM}$ HEPES, $1.5 \mathrm{mM}$ EDTA, $10 \%$ glycerol, $1.0 \mathrm{mM}$ dithiothreitol) for $10 \mathrm{~min}$ followed by a $5 \mathrm{~min}$ incubation at $20{ }^{\circ} \mathrm{C}$ with unlabeled excess competitor. The incubation mixtures were irradiated by using a FOTODYNE u.v. transilluminator at $>205 \mathrm{~nm}$ for $30 \mathrm{~min}$ at $20{ }^{\circ} \mathrm{C}$. Samples were then mixed with $20 \mu \mathrm{l}$ of an SDS loading buffer, heated to $95^{\circ} \mathrm{C}$ for $5 \mathrm{~min}$ and then subjected to electrophoresis on SDS-6\% polyacrylamide gels. Molecular weights of u.v. cross-linked nuclear ligand-AhR complexes were calculated from ${ }^{14} \mathrm{C}$-methylated standards obtained from Amersham Corp. (Arlington Heights, IL, USA). Immunodepletion of the AhR was carried out by incubating $10 \mu \mathrm{g}$ of nuclear extract with $1 \mu \mathrm{g}$ of either AhR antibody or mouse IgG for $1 \mathrm{~h}$ at $25{ }^{\circ} \mathrm{C}$. The immunodepleted extract was then used in the u.v. cross-linking studies as described above.

\section{Statistics}

All data points for transient transfection were repeated at least three times (separate experiments). Results were analyzed by ANOVA and Scheffe's post hoc test and are presented as means \pm s.D.s or s.E.s as indicated.

\section{RESULTS}

\section{Comparative effects of ER antagonists and TCDD (AhR agonist) on Hsp 27 gene expression induced by $E_{2}$}

Previous studies showed that $\mathrm{E}_{2}$ induced Hsp 27 gene expression 4-24 h after treatment (Porter et al. 1996), and the results illustrated in Fig. 1A show that $10 \mathrm{nM} \mathrm{E} \mathrm{E}_{2}$ alone induced a $3 \cdot 2$-fold increase in Hsp 27 mRNA levels in MCF-7 cells after hormone treatment for $12 \mathrm{~h}$. The effects of the pure antiestrogen ICI $164,384(1 \mu \mathrm{M})$ alone or in combination with $\mathrm{E}_{2}$ gave surprising results; ICI
A.
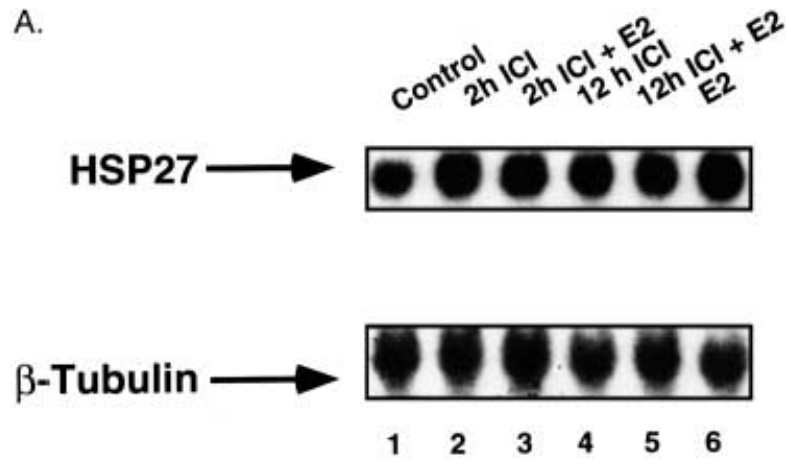

B.
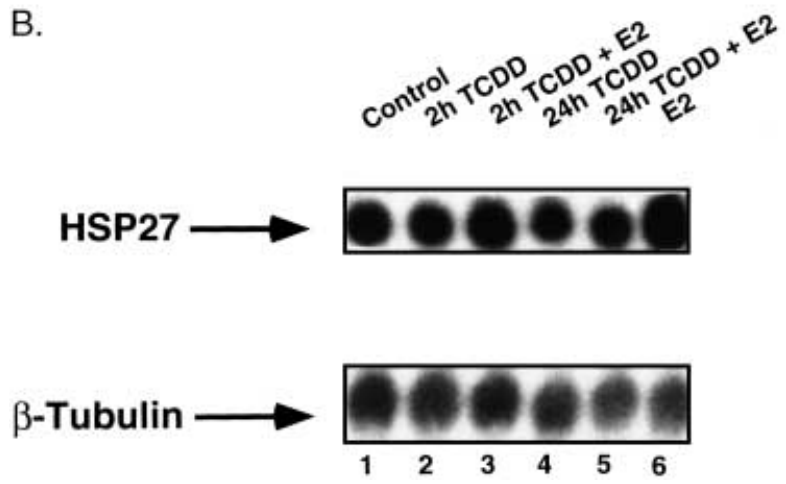

FIGURE 1. Modulation of estrogen-induced Hsp 27 gene expression by antiestrogens and TCDD. (A) Induction by ICI 164,384. Cells were treated with DMSO (lane 1), $10 \mathrm{nM} \mathrm{E}_{2}$ alone for $12 \mathrm{~h}$ (lane 6), and $1 \mu \mathrm{M}$ ICI 164,384 for 2 and $12 \mathrm{~h}$ (lanes 2 and 5 respectively). Cells were also co-treated with $\mathrm{E}_{2}$ for $12 \mathrm{~h}$ and ICI 164,384 for 2 and $12 \mathrm{~h}$ (lanes 3 and 5 respectively). Cell extracts were obtained and total RNA was isolated and subjected to Northern analysis as described under the Materials and Methods section. The intensity values in lanes 2-6 relative to control (lane $1,100 \pm 3 \cdot 5 \%$ ) were $229 \pm 54$, $276 \pm 29,263 \pm 33,295 \pm 19$ and $324 \pm 27 \%$ (lanes $2-6$ respectively; means \pm s.D.s for three determinations). Intensity values for Hsp 27 mRNA were standardized to $\beta$-tubulin mRNA which was used as an internal control.

(B) Induction by $\mathrm{E}_{2}$, TCDD and their combination. Cells were treated with $10 \mathrm{nM} \mathrm{E}, 10 \mathrm{nM}$ TCDD or their combination as described above, and mRNA intensities for the different treatment groups were determined as described in the Materials and Methods section. The intensity values in lanes 2-6 relative to control (lane 1, $100 \pm 19 \%)$ were $81 \pm 15,111 \pm 5,91 \pm 1,89 \pm 11$ and $180 \pm 11 \%$ (lanes $2-6$ respectively; means \pm s.Ds for three determinations). Intensity values for Hsp 27 mRNA were standardized to $\beta$-tubulin mRNA as described above. There was a significant decrease $(P<0 \cdot 05)$ in Hsp 27 mRNA levels in the cotreated $\left(\mathrm{E}_{2}+\mathrm{TCDD}\right)$ cells compared with those treated with $\mathrm{E}_{2}$ alone.

164,384 alone $(2$ or $12 \mathrm{~h}$ ) induced a $2 \cdot 3$ - to $2 \cdot 6$-fold increase in Hsp $27 \mathrm{mRNA}$ levels and in combination with $\mathrm{E}_{2}$ no inhibitory response was observed. 
These results are expressed as means \pm s.D.s for three separate determinations, and similar results were obtained in a duplicate experiment (data not shown). The results in Fig. 1B summarize effects of $10 \mathrm{nM}$ TCDD alone, $10 \mathrm{nM} \mathrm{E}_{2}$ alone and their combination on Hsp 27 mRNA levels in MCF-7 cells. In this experiment, $10 \mathrm{nM} \mathrm{E}_{2}$ only caused a 1.8-fold induction of Hsp 27 mRNA levels $24 \mathrm{~h}$ after treatment (lane 6), whereas no induction was observed in cells treated with $10 \mathrm{nM}$ TCDD alone for 2 or $24 \mathrm{~h}$ (lanes 2 and 4). In contrast, Hsp 27 mRNA levels induced by $\mathrm{E}_{2}$ were significantly inhibited after 2 or $24 \mathrm{~h}$ treatment with TCDD. Thus, TCDD but not ICI 164,384 inhibited induction of $\mathrm{Hsp} 27$ gene expression by $\mathrm{E}_{2}$.

\section{Interactions of direct-acting antiestrogens and TCDD on $\mathrm{E}_{2}$-induced transactivation in transient transfection assays}

pHsp27 contains the $\mathrm{E}_{2}$-responsive -108 to +23 region of the Hsp 27 gene promoter in pBLCAT3, and induction by $\mathrm{E}_{2}$ in MCF-7 cells was observed only after cotransfection with $\mathrm{hER} \alpha$ as previously reported for studies using constructs containing other $\mathrm{E}_{2}$-responsive gene promoter inserts (Moore et al. 1994, Krishnan et al. 1995, Porter et al. 1996, 1997, Gillesby et al. 1997, Duan et al. 1998, 1999, Sun et al. 1998, Wang et al. 1998, 1999, Dong et al. 1999, Qin et al. 1999, Xie et al. 1999, Saville et al. 2000). For relatively weak $\mathrm{E}_{2}$-responsive promoters, endogenous ER $\alpha$ levels are insufficient for cells overexpressing the transfected constructs, and transactivation by $\mathrm{E}_{2}$ is observed only after transfection with hER. In MCF-7 cells transfected

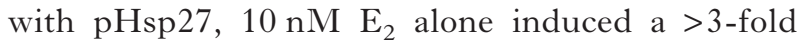
increase in CAT activity and $2 \cdot 5$-fold induction was observed for $1 \mu \mathrm{M}$ ICI 164,384 (Fig. 2A). Previous studies have identified an $\mathrm{E}_{2}$-responsive $\mathrm{Sp} 1(\mathrm{~N})_{10}$ ERE half-site motif in this promoter, and mutation of these sites resulted in loss of induction by $\mathrm{E}_{2}$ (Porter et al. 1996). Ten nM TCDD did not affect CAT activity in MCF-7 cells transfected with pHsp27 compared with solvent (DMSO) control. ICI 164,384 in combination with $\mathrm{E}_{2}$ gave results similar to that observed for the antiestrogen alone and CAT activity was lower than observed for $\mathrm{E}_{2}$ alone. In contrast, cotreatment of MCF-7 cells with TCDD plus $\mathrm{E}_{2}$ resulted in $>70 \%$ inhibition of hormone-induced activity. The comparative ER $\alpha$ agonist/antagonist activities of tamoxifen, 4'hydroxytamoxifen and ICI 182,780 were also determined (Fig. 2B), and the three direct-acting antiestrogens all exhibited agonist activities as observed for ICI 164,384 and their antiestrogenic effects were minimal. The effects of direct-acting antiestrogens were also investigated in MCF-7 cells transfected with pHsp27 and wild-type hER or variants HE11, HE19 and HE15 (Fig. 2C). $\mathrm{E}_{2}$, 4'-hydroxytamoxifen and ICI 164,384 induced reporter gene activity in cells cotransfected with wild-type $\mathrm{hER}$; in contrast, $\mathrm{E}_{2}$ (but not antiestrogens) also induced CAT activity in cells transfected with HE11 which contains a deletion of the DNA binding domain of ER $\alpha$. Ligand-induced transactivation was not observed using HE15 or HE19 that contain a $\mathrm{C}$-terminal deletion of activation function 2 (AF2) and an N-terminal deletion of AF1 respectively. These results for $\mathrm{E}_{2}$ plus $\mathrm{hER} \alpha$ and the variant expression plasmids HE11, HE15 and HE19 were similar to those reported using a construct containing a consensus GC-rich promoter insert with a GGCGGG sequence that binds Sp1 protein with high affinity (Saville et al. 2000). The deletion constructs used in this study were derived from human ER (HE0) (Kumar et al. 1986, 1987) containing a $\mathrm{G} 400 \mathrm{~V}$ point mutation; however, ongoing studies with wild-type ER (HEG0) variants HEG11 and HEG19 give results that are similar to those observed with HE11 and HE15 (unpublished results). The pure antiestrogens (ICI 164,384 and 182,780 ) do not induce reporter gene activity in cells transfected with constructs containing ERE-dependent promoters and hER or ER-AF1 (Tzukerman et al. 1994, McDonnell et al. 1995, Yoon et al. 2000), whereas $\mathrm{E}_{2}$ is active using pERE and hER $\alpha$ or ER-AF1 expression plasmids (Fig. 2D). Saville and co-workers (2000) reported that $\mathrm{ER} \alpha / \mathrm{Sp} 1$ activation of a $\mathrm{GC}$-rich promoter in MCF-7 cells was AF1-dependent and induced by $\mathrm{E}_{2}$ and ICI 182,780, and the results in Fig. 2D also show that both $\mathrm{E}_{2}$ and antiestrogens induced CAT activity in cells transfected with pHsp27 and ER-AF1. These results are consistent with the importance of AF1 for estrogen/antiestrogen activation of GC-rich sites (Saville et al. 2000), and we have also observed similar induction with other GC-rich promoters (K Kim, unpublished observations).

\section{Identification of a functional iDRE in the Hsp 27 gene promoter}

Pentanucleotide GCGTG sequences have previously been identified as functional iDREs in the cathepsin D, c-fos and pS2 gene promoters (Krishnan et al. 1995, Gillesby et al. 1997, Duan et al. 1999), and a similar sequence is present at -3 to +2 in the Hsp 27 gene promoter. The role of this motif in mediating inhibitory AhR-ER $\alpha$ crosstalk was confirmed in MCF-7 cells transiently 
A. pHsp27 (MCF-7 cells)

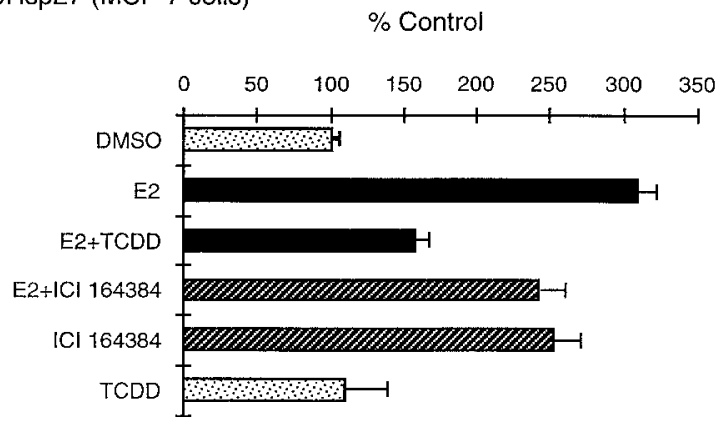

B. pHsp27 (MCF-7 cells)

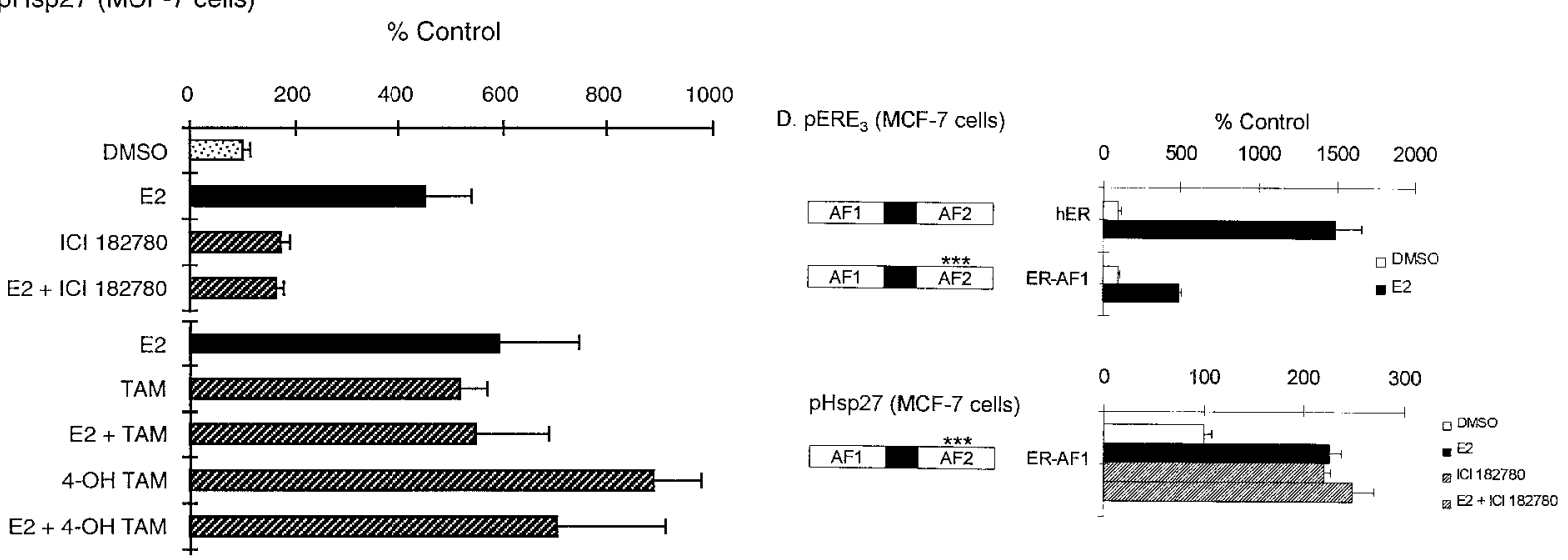

C. pHsp27 (MCF-7 cells)

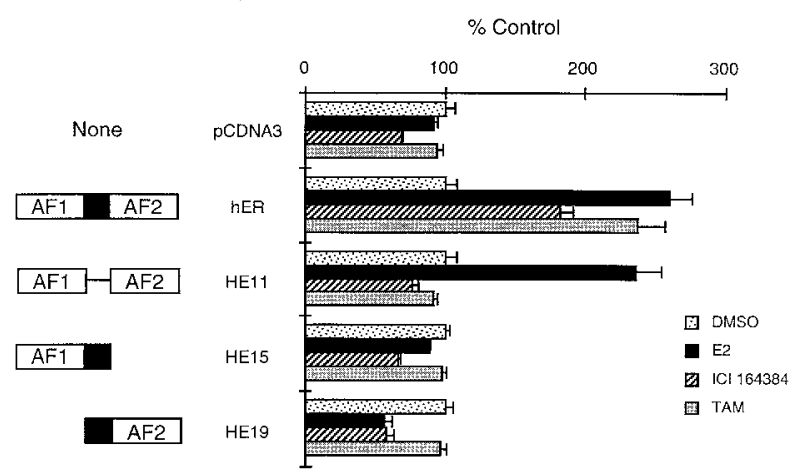

FIGURE 2. Effects of $\mathrm{E}_{2}$, TCDD, antiestrogens and combinations (with $\mathrm{E}_{2}$ ) on CAT activity in MCF-7 cells transfected with pHsp27. (A) Effects of $\mathrm{E}_{2}$, TCDD, ICI 164,384, and their combinations. Cells were transiently transfected with the pHsp27 and wild-type ER $\alpha$, treated with $\mathrm{E}_{2}$, TCDD, ICI 164, 834, TCDD+E , $_{2}$ or ICI $164,384+\mathrm{E}_{2}$, and CAT activity was determined as described in the Materials and Methods section. $\mathrm{E}_{2}$ and ICI 164,384 significantly induced CAT activity, TCDD alone did not induce activity but in combination with $\mathrm{E}_{2}$, there was a significant $(P<0 \cdot 05)$ decrease in the hormone-induced response. (B) Effects of other antiestrogens and their interactions with $\mathrm{E}_{2}$. ICI 182,780 , tamoxifen and $4^{\prime}$-hydroxytamoxifen, and $\mathrm{E}_{2}$ all induced $(P<0 \cdot 05)$ CAT activity in MCF-7 cells transfected with pHsp 27 (and wild-type ER $\alpha$ ), and only ICI 182,780 partially inhibited $(P<0 \cdot 05) \mathrm{E}_{2}$ action. (C) Ligand-dependent transactivation of pHsp27 in MCF-7 cells cotransfected with wild-type and variant $\mathrm{ER} \alpha$ expression plasmids. Transfection studies and treatments were carried out as described above; however, cells were transfected with wild-type (hER) or variant (HE11, HE15 or HE19) ER $\alpha$ expression plasmids. ICI 164,384, $\mathrm{E}_{2}$ and tamoxifen induced activity with wild-type $\mathrm{ER} \alpha(P<0 \cdot 05)$, whereas only $\mathrm{E}_{2}$ induced activity in cells transfected with HE11. No induction responses were observed using HE15 or HE19. (D) Ligand-dependent transactivation by ER-AF1. MCF-7 cells were transfected with pERE $\mathrm{E}_{3}$ or pHsp27 and hER or ER-AF1, and CAT was determined as described in the Materials and Methods section. $\mathrm{E}_{2}$ significantly induced activity in cells transfected with both constructs and hER or ER-AF1; moreover, ICI 182,780 alone and in combination with $\mathrm{E}_{2}$ also induced activity in cells transfected with pHsp27 and ER-AF1. ICI 182,780 inhibited induction in cells transfected with pERE ${ }_{3}$ and hER or ER-AF1 (data not shown). All experiments were carried out in triplicate and results are expressed as means \pm s.D.s.

transfected with $\mathrm{pHsp} 27 \mathrm{~m} 1$ that contains mutation in the pentanucleotide sequence (Fig. 3A). The effects of $\mathrm{E}_{2}$, ICI 164,384 , TCDD and $\mathrm{E}_{2}$ plus ICI 164,384 on CAT activity in cells transfected with pHsp $27 \mathrm{~m} 1$ were similar to those observed for the wild-type construct (Fig. 2); however, in cells cotreated with $\mathrm{E}_{2}$ plus TCDD, the inhibitory effect of TCDD was not observed using the mutant construct. Further confirmation for the role of the AhR in mediating the effects of TCDD was obtained using variant $\mathrm{BaP}^{\mathrm{r}} \mathrm{MCF}-7$ cells that express low levels of the $\mathrm{AhR}$ and are $\mathrm{Ah}$ nonresponsive (Moore et al. 1994). Transfection studies in this cell line with pHsp27 showed the $\mathrm{E}_{2}$ and ICI 164,384 induced reporter gene activity; however, inhibition of this response was not 


\section{A. pHsp27.m1 (MCF-7 cells)}

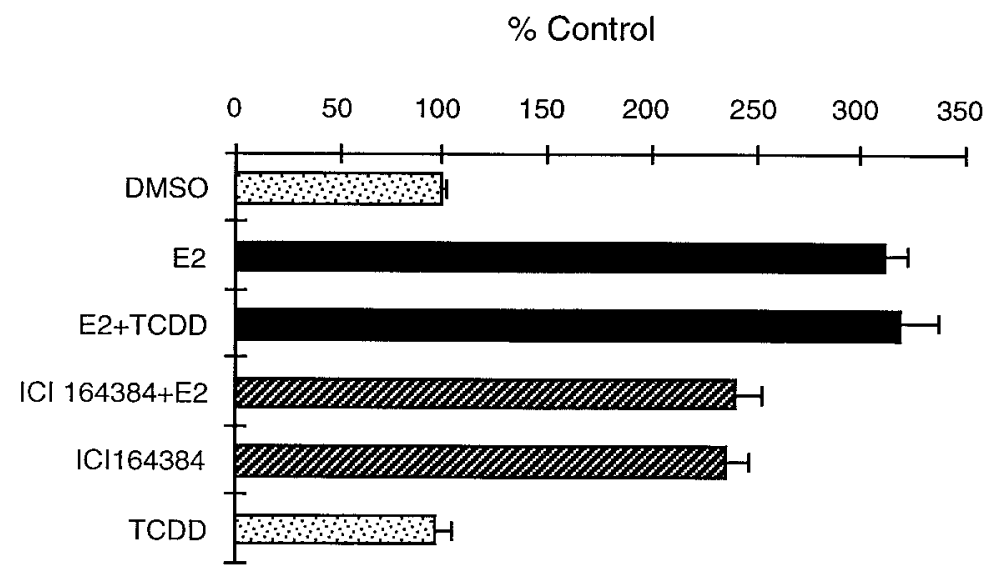

B. pHsp27 (BaPR-resistant MCF-7 cells)

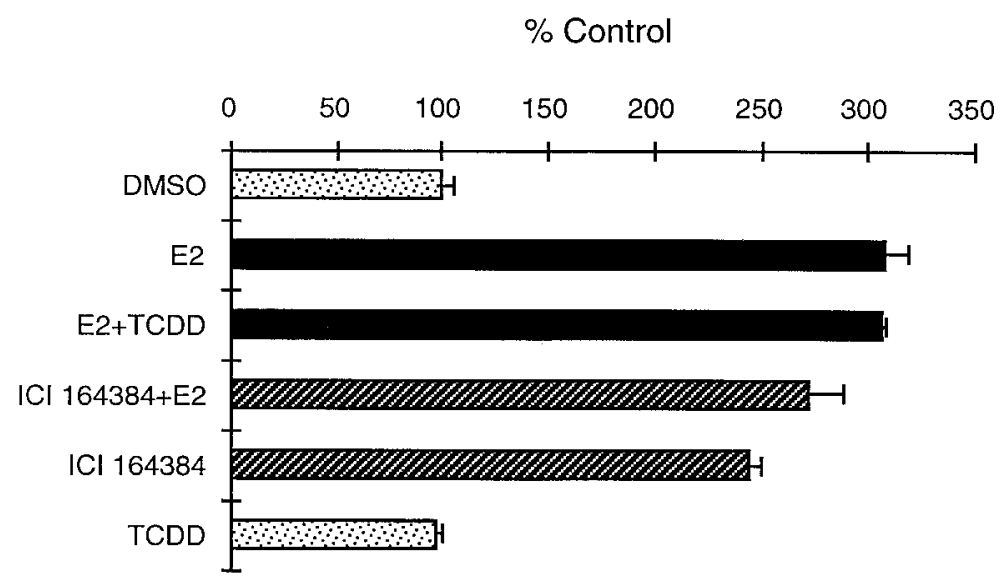

FIGURE 3. Role of the AhR complex and iDRE in AhR-ER $\alpha$ cross-talk. (A) Transfection with pHsp27 m1 in MCF-7 cells. MCF-7 cells were transfected and treated as described in Fig. 2 and CAT activities were determined. CAT activities were significantly induced $(P<0 \cdot 05)$ after treatment with $\mathrm{E}_{2}, \mathrm{E}_{2}+\mathrm{ICI} 164,384$, or ICI 164,384 alone; TCDD did not inhibit $\mathrm{E}_{2}$-induced CAT activity. (B) Transfection of pHsp27 in BaP-resistant MCF-7 cells. BaP-resistant MCF-7 cells were transfected with pHsp27 as described in Fig. 2, treated with chemicals, and CAT activities determined as described in the Materials and Methods section. $\mathrm{E}_{2}$ and ICI 164,384 significantly induced CAT activity $(P<0 \cdot 05)$ and neither ICI 164,384 or TCDD inhibited hormone-induced activity.

observed in cells cotreated with $\mathrm{E}_{2}$ plus TCDD (Fig. 3B).

Direct binding of the AhR complex to the iDRE within the Hsp 27 oligonucleotide was not observed in gel mobility shift assays (data not shown), and this was consistent with results of previous studies showing that AhR complex-iDRE interactions were non-detectable using gel mobility shift assays (Krishnan et al. 1995, Gillesby et al. 1997, Duan et al. 1999). In contrast, results of cross-linking studies using BrdU-substituted $\left[{ }^{32} \mathrm{P}\right] \mathrm{Hsp} 27$ confirmed interactions between the nuclear AhR complex and the iDRE motif (Fig. 4). Incubation of a BrdU-substituted Hsp 27 oligonucleotide with nuclear extracts from MCF-7 cells treated with TCDD gave a $190 \mathrm{kDa}$ cross-linked band (lanes 3 and 6); the band intensity was decreased by co-incubation with unlabeled DRE (lane 4) but not decreased after co-incubation with unlabeled mutant DRE (lane 5). In a separate experiment 


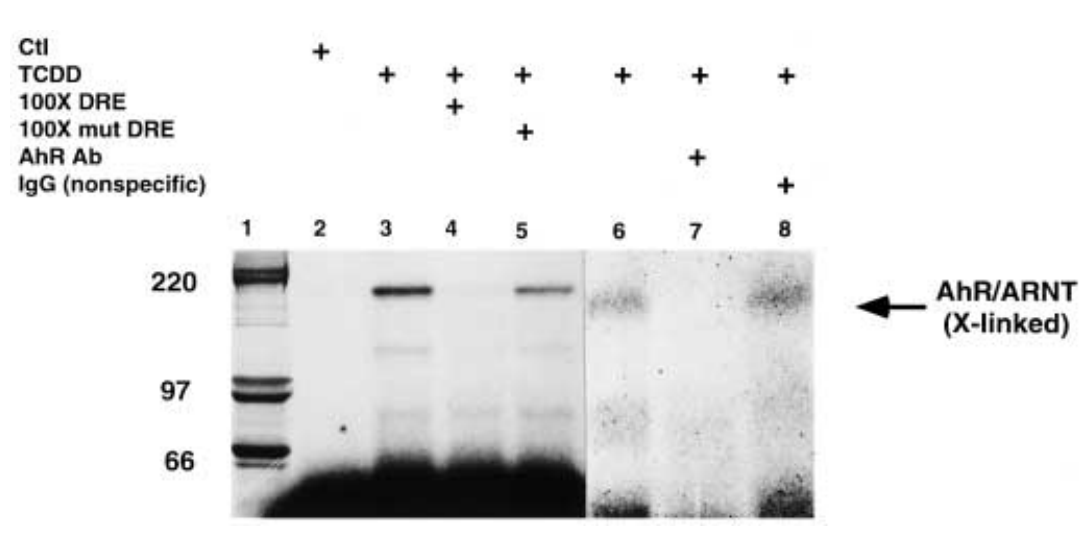

FIgURE 4. Cross-linking of the nuclear AhR complex with BrdU-DRE. The BrdU-DRE oligonucleotide was incubated with nuclear extracts from cells treated with DMSO (Ctl) (lane 2), TCDD (lanes 3 and 6) or TCDD in the presence of 100-fold excess of unlabeled wild-type DRE (lane 4) or mutant (mut) DRE (lane 5). Nuclear extracts were pre-incubated with either AhR antibody (AhR Ab) (lane 7) or nonspecific IgG (lane 8). Incubation, cross-linking and electrophoresis of the cross-linked complexes were carried out as described in the Materials and Methods section. The $200 \mathrm{kDa}$ cross-linked (X-linked) AhR complexes (arrow) were visualized by autoradiography. Molecular weights were determined with ${ }^{14} \mathrm{C}$-labeled protein standards purchased from Amersham Corp. (lane 1).

(lanes 6-8), pre-incubation of the nuclear extract with AhR antibodies decreased formation of the $190 \mathrm{kDa}$ cross-linked band (lane 7), whereas pre-incubation with nonspecific $\operatorname{IgG}$ did not affect formation of the cross-linked band (lane 8). These results confirm that the AhR complex interacts with the iDRE in the Hsp 27 gene promoter and complements results of previous studies showing that the nuclear AhR complex cross-links with core pentanucleotide iDREs in the cathepsin D, c-fos and pS2 gene promoters (Krishnan et al. 1995, Gillesby et al. 1997, Duan et al. 1999).

\section{DISCUSSION}

Hsp 27 is an estrogen-regulated gene in breast cancer cells and there is evidence that this protein plays a role in breast cancer cell growth and drug resistance. Direct-acting antiestrogens such as tamoxifen are used extensively for treatment of breast cancer; however, there is concern that long-term use of tamoxifen increases the risk for endometrial cancer due to the partial ER agonist activity of this drug in the uterus (Jordan 1984, 1993, Cook et al. 1995, Jordan \& Assikis 1995, MacGregor \& Jordan 1998). New steroidal antiestrogens such as ICI 182,780 and 164,384 have also been developed as antiestrogens that exhibit ER antagonist activities in rodent mammary tumors and uteri, and in human endometrial and breast cancer cell lines (Wakeling et al. 1991, Wakeling 1993, DeFriend et al. 1994, Wakeling \& Bowler 1988, Castro-Rivera et al. 1999). Endocrine therapy for breast cancer also includes indirect antiestrogens such as aromatase inhibitors that block estrogen formation in target tissues (Brodie \& Santen 1994).

Ligands for the retinoic acid, vitamin D and peroxisome proliferator-activated receptors activate signaling pathways that block estrogen action and various selective modulators are being developed for treatment of breast cancer (Fraker et al. 1984, Colston et al. 1992, Hong \& Itri 1994, Elstner et al. 1998). Research in this laboratory has focused on the mechanisms of inhibitory AhR-ER cross-talk and development of selective AhR modulators (SAhRMs) for treatment of breast cancer (Safe 1995, 1999, Porter \& Safe 1998, Zacharewski \& Safe 1998, Safe et al. 1999). Since Hsp 27 may play an important role in mammary cancer, we have investigated the comparative antiestrogenic activities of the 'pure' steroidal antiestrogens ICI 164,384 and TCDD, a prototypical AhR agonist. Previous studies showed that TCDD inhibits $\mathrm{E}_{2}$-induced $\mathrm{pS} 2$, cathepsin $\mathrm{D}$, prolactin receptor, c-fos and progesterone receptor gene expression in MCF-7 cells (Harper et al. 1994, Zacharewski et al. 1994, Krishnan et al. 1995, Lu et al. 1996, Gillesby et al. 1997, Duan et al. 1999), and similar results were obtained in this study for Hsp 27 (Fig. 1A). Moreover, inhibition of $\mathrm{E}_{2}$-induced Hsp 27 gene expression by TCDD was also observed using pHsp 27 and a functional iDRE was characterized at the transcription start site $(-3$ to +2$)$. Functional iDREs have previously been identified in the cathepsin D, c-fos and pS2 gene promoters (Krishnan et al. 1995, Gillesby et al. 1997, Duan et al. 1999), and the results show that the mechanisms of AhR-mediated 
inhibition of $\mathrm{ER} \alpha$ action in breast cancer cells is gene promoter specific. Interaction of the $\mathrm{AhR}$ complex at the transcription start site in the Hsp 27 gene promoter inhibits induction by $\mathrm{E}_{2}$ but not basal activity, suggesting that interaction of the DNA-bound ER $\alpha-S p 1$ complex with other nuclear factors and/or the basal transcription machinery may be blocked. In contrast, inhibitory AhR-ER $\alpha$ cross-talk at iDREs in the c-fos and pS2 gene promoters involves quenching or masking at $\mathrm{E}_{2}$-responsive $\mathrm{GC}$-rich and AP1 motifs, whereas AhR complex-iDRE interactions in the cathepsin D gene promoter blocks $\mathrm{ER} \alpha-\mathrm{Sp} 1$ complex formation at an $\operatorname{Sp} 1(\mathrm{~N})_{23}$ ERE half-site motif.

The antiestrogenic activities of the steroidal ICI 164,384 and 182,780 have been extensively characterized, and these compounds have been designated as 'pure' antiestrogens (Wakeling \& Bowler 1988, Wakeling et al. 1991, Wakeling 1993, DeFriend et al. 1994). Conflicting mechanisms of action have been proposed for these compounds (Reese \& Katzenellenbogen 1991, Dauvois et al. 1993, Parker 1993, Metzger et al. 1995) and recent studies suggest that their ER antagonist activities are associated with ligand-induced changes in the conformation of ER $\alpha$ that prevent interactions with coactivators and other nuclear proteins required for transactivation (Norris et al. 1999, Paige et al. 1999, Van Den Bemd et al. 1999). The results of our studies on the antiestrogenic activity of ICI 164,384 were unexpected since the pure antiestrogen induced Hsp 27 gene mRNA levels in MCF-7 cells and both steroidal (ICI 164,384 and ICI 182,780) and non-steroidal (tamoxifen/hydroxytamoxifen) antiestrogens were $\mathrm{ER} \alpha$ agonists in transient transfection assays using pHsp27 and wild-type $\mathrm{ER} \alpha$ (Fig. 2). However, results obtained with wild-type and truncated $\mathrm{ER} \alpha$ constructs demonstrate that only $\mathrm{E}_{2}$ activated reporter gene activity in MCF-7 cells transfected with HE11 (a DNA binding domain-deficient variant) and $\mathrm{pHsp} 27$ and results similar to those summarized in Fig. $2 \mathrm{C}$ were also observed using a construct containing a consensus GC-rich Sp1 binding site motif (Saville et al. 2000). These results indicate important ligand structure-dependent differences in HE11/Sp1 activation, suggesting that interactions with the deleted DNA binding domain of $\mathrm{ER} \alpha$ are required for antiestrogen-induced gene expression. These data suggest that activation of the Hsp 27 gene by $\mathrm{E}_{2}$ occurs primarily through $\mathrm{ER} \alpha / \mathrm{Sp} 1$ action through the GC-rich site, since results obtained using the cathepsin D and transforming growth factor $\alpha$ gene promoters, which also have $\mathrm{E}_{2}$-responsive Sp1(N) $)_{x}$ RE half-site motifs, show that DNA binding by $\mathrm{ER} \alpha$ is required for transactivation
(Krishnan et al. 1994, 1995, Vyhlidal et al. 2000). Moreover, ICI 164,384 inhibits induction of cathepsin D gene/gene promoter expression in MCF-7 cells (Krishnan et al. 1994).

$\mathrm{ER} \alpha$ interacts with several nuclear proteins that modulate ER action, and these include multiple coactivators that primarily interact with the AF2 domain of ERa (Glass et al. 1997, Zwijsen et al. 1997, Lemon \& Freedman 1999, McKenna et al. 1999, Johansson et al. 2000, Resnick et al. 2000, Ying \& Lin 2000). For example, both ER $\alpha-A P 1$ and $\mathrm{ER} \alpha-\mathrm{Sp} 1$ are ligand-activated transcription factor complexes in which $\mathrm{ER} \alpha$ does not directly bind DNA but interacts with another DNA-bound transcription factor. However, there are several striking differences in $\mathrm{ER} \alpha-\mathrm{Sp} 1$ vs $\mathrm{ER} \alpha-\mathrm{AP} 1$ action. Previous studies show that estrogens and antiestrogens induce gene expression through $\mathrm{ER} \alpha-\mathrm{Sp} 1$ interactions with GC-rich promoterreporter constructs in breast, prostate and endometrial cancer cell lines but not in HeLa cells (Saville et al. 2000), and similar results were observed in this study using MCF-7 cells. In contrast, $\mathrm{E}_{2}$ but not tamoxifen or ICI 164,384, induced $\mathrm{ER} \alpha-\mathrm{AP} 1$-dependent activity in breast cancer cells, whereas estrogens and antiestrogens were agonists for this response in HeLa cells (Webb et al. 1995), and subsequent studies have reported other differences between $\operatorname{ER} \alpha$ and $\operatorname{ER} \beta$ interactions with AP1 or Sp1 (Webb et al. 1995, 1999, Paech et al. 1997, Saville et al. 2000). A recent study showed that ER $\alpha-A P 1$ activation by $E_{2}$ was associated with AF2-dependent interactions with p160 coactivators, whereas antiestrogen activation utilized different pathways that may involve interactions with corepressors (Webb et al. 1999). Mutations in the AF2 domain of ER $\alpha$ did not affect estrogen or antiestrogen activation of $\mathrm{pHsp} 27$ in MCF-7 cells (Fig. 2D), whereas this domain is important for ER $\alpha-\mathrm{AP} 1$ action by $\mathrm{E}_{2}$ (Webb et al. 1999).

Thus, our results suggest that some $E_{2}$ responsive genes activated by $\mathrm{ER} \alpha-\mathrm{Sp} 1$ interactions with GC-rich promoter elements may also be upregulated by steroidal 'pure' antiestrogens such as ICI 164,384. Elgort and co-workers (1996) previously reported that ICI 164,384 and tamoxifen induce retinoic acid receptor $\alpha 1$ gene expression in MCF-7 cells and this is consistent with subsequent identification of three $\mathrm{E}_{2}$-responsive $\mathrm{GC}$-rich sites in the proximal promoter region of this gene (Sun et al. 1998). Thus, there is a concordance between gene expression and transient transfection assays for the induction of Hsp 27 and retinoic acid receptor $\alpha 1$ gene expression by ICI 164,384 . However, the presence of $\mathrm{E}_{2}$-responsive $\mathrm{GC}$-rich promoter 
elements does not necessarily predict ICI 164,384inducibility of the corresponding genes. For example, $b c l 2$, c-fos, insulin-like growth factor binding protein 4 and $\mathrm{E} 2 \mathrm{~F} 1$ gene promoters contain $\mathrm{E}_{2}$-responsive GC-rich motifs (Duan et al. 1998, Dong et al. 1999, Qin et al. 1999, Wang et al. 1999) and steroidal antiestrogens inhibited induction of these genes by $\mathrm{E}_{2}$. The ER $\alpha$ agonist activity of ICI 164,384 appears to be dependent not only on the ligand-induced conformational changes of $\mathrm{ER} \alpha$ that facilitate interactions with other transcription factors, but also on promoter context, and current studies are focused on further defining molecular mechanisms of ICI 164,384 action.

\section{ACKNOWLEDGEMENTS}

This work was supported by the NIH Grants ES04176 and ES09106 and the Texas Agricultural Experiment Station. S S is a Sid Kyle Professor of Toxicology.

\section{REFERENCES}

Adams DJ \& McGuire WL 1985 Quantitative enzyme-linked immunosorbent assay for the estrogen-regulated Mr 24000 protein in human breast tumors: correlation with estrogen and progesterone receptors. Cancer Research 45 2445-2449.

Arts HJ, Hollema H, Lemstra W, Willemse PH, De Vries EG, Kampinga HH \& Van der Zee AG 1999 Heat-shock-protein27 (hsp27) expression in ovarian carcinoma: relation in response to chemotherapy and prognosis. International Fournal of Cancer 84 234-238.

Brodie AM \& Santen RJ 1994 Aromatase and its inhibitors in breast cancer treatment - overview and perspective. Breast Cancer Research and Treatment 30 1-6.

Castro-Rivera E, Wormke M \& Safe S 1999 Estrogen and aryl hydrocarbon responsiveness of ECC-1 endometrial cancer cells. Molecular and Cellular Endocrinology 150 11-21.

Ciocca DR, Adams DJ, Edwards DP, Bjerke RJ \& McGuire WL 1983 Distribution of estrogen-induced protein with a molecular weight of 24000 in normal and malignant human tissues and cells. Cancer Research 43 1204-1210.

Ciocca DR, Stati AO \& de Castro Amprino CM 1990 Colocalization of estrogen and progesterone receptors with an estrogen-regulated heat shock protein in paraffin sections of human breast and endometrial cancer tissue. Breast Cancer Research and Treatment 16 243-251.

Ciocca DR, Oesterreich S, Chamness GC \& McGuire WL 1993 Biological and clinical implications of heat shock protein 27, 000 (Hsp27): a review. Fournal of the National Cancer Institute 85 1558-1570.

Colston KW, Chander SK, Mackay AG \& Coombes RC 1992 Effects of synthetic vitamin D analogues on breast cancer cell proliferation in vivo and in vitro. Biochemical Pharmacology 44 693-702.

Cook LS, Weiss NS, Schwartz SM, White E, McKnight B, Moore DE \& Daling JR 1995 Population-based study of tamoxifen therapy and subsequent ovarian, endometrial, and breast cancers. Fournal of the National Cancer Institute $\mathbf{8 7}$ 1359-1364.
Dauvois S, White R \& Parker MG 1993 The antiestrogen ICI 182780 disrupts estrogen receptor nucleocytoplasmic shuttling. Fournal of Cell Science 106 1377-1388.

DeFriend DJ, Howell A, Nicholson RI, Anderson E, Dowsett M, Mansel RE, Blamey RW, Bundred NJ, Robertson JF \& Saunders C 1994 Investigation of a new pure antiestrogen (ICI 182780) in women with primary breast cancer. Cancer Research 54 408-414.

Dong L, Wang W, Wang F, Stoner M, Reed JC, Harigai M, Kladde M, Vyhlidal C \& Safe S 1999 Mechanisms of transcriptional activation of $b c l-2$ gene expression by $17 \beta$-estradiol in breast cancer cells. Fournal of Biological Chemistry 174 32099-32107.

Duan R, Porter W \& Safe S 1998 Estrogen-induced c-fos protooncogene expression in MCF-7 human breast cancer cells: role of estrogen receptor Sp1 complex formation. Endocrinology 139 1981-1990.

Duan R, Porter W, Samudio I, Vyhlidal C, Kladde M \& Safe S 1999 Transcriptional activation of c-fos protooncogene by $17 \beta$-estradiol: mechanism of aryl hydrocarbon receptormediated inhibition. Molecular Endocrinology 13 1511-1521.

Dunn DK, Whelan RD, Hill B \& King RJ 1993 Relationship of HSP27 and oestrogen receptor in hormone sensitive and insensitive cell lines. Fournal of Steroid Biochemistry and Molecular Biology 46 469-479.

Edwards DP, Adams DJ, Savage N \& McGuire WL 1980 Estrogen induced synthesis of specific proteins in human breast cancer cells. Biochemical and Biophysical Research Communications 93 804-812.

Edwards DP, Adams DJ \& McGuire WL 1981 Estradiol stimulates synthesis of a major intracellular protein in a human breast cancer cell line (MCF-7). Breast Cancer Research and Treatment 1 209-223.

Elgort MG, Zou A, Marschke KB \& Allegretto EA 1996 Estrogen and estrogen receptor antagonists stimulate transcription from the human retinoic acid receptor- $\alpha 1$ promoter via a novel sequence. Molecular Endocrinology 10 477-487.

Elstner E, Muller C, Koshizuka K, Williamson EA, Park D, Asou H, Shintaku P, Said JW, Heber D \& Koeffler HP 1998 Ligands for peroxisome proliferator-activated receptor gamma and retinoic acid receptor inhibit growth and induce apoptosis of human breast cancer cells in vitro and in BNX mice. PNAS $958806-8811$.

Fraker LD, Halter SA \& Forbes JT 1984 Growth inhibition by retinol of a human breast carcinoma cell line in vitro and in athymic mice. Cancer Research 44 5757-5763.

Fuqua SA, Blum-Salingaros M \& McGuire WL 1989 Induction of the estrogen-regulated ' $24 \mathrm{~K}$ ' protein by heat shock. Cancer Research 49 4126-4129.

Gillesby B, Santostefano M, Porter W, Wu ZF, Safe S \& Zacharewski T 1997 Identification of a motif within the 5 '-regulatory region on $\mathrm{pS} 2$ which is responsible for $\mathrm{Ap} 1$ binding and TCDD-mediated suppression. Biochemistry 36 6080-6089.

Glass CK, Rose DW \& Rosenfeld MG 1997 Nuclear receptor coactivators. Current Opinions in Cell Biology $9222-232$.

Guenal I, Sidoti-de Fraisse C, Gaumer S \& Mignotte B 1997 Bcl-2 and Hsp27 act at different levels to suppress programmed cell death. Oncogene 15 347-360.

Harper N, Wang X, Liu H \& Safe S 1994 Inhibition of estrogen-induced progesterone receptor in MCF-7 human breast cancer cells by aryl hydrocarbon $(\mathrm{Ah})$ receptor agonists. Molecular and Cellular Endocrinology 104 47-55.

Hong WK \& Itri LM 1994 Retinoids and human cancer. In The Retinoids: Biology, Chemistry, and Medicine, pp 597630. Eds MB Sporn, AB Roberts \& DS Goodman. New York: Raven. 
Horne GM, Angus B, Wright C, Needham G, Nicholson S, Harris AL, Innes B \& Horne CH 1988 Relationships between oestrogen receptor, epidermal growth factor receptor, ER-D5, and P24 oestrogen regulated protein in human breast cancer. Fournal of Pathology 155 143-150.

Hsu PL \& Hsu SM 1998 Abundance of heat shock proteins (hsp89, hsp60, and hsp27) in malignant cells of Hodgkin's disease. Cancer Research 58 5507-5513.

Jakob U \& Buchner J 1994 Assisting spontaneity: the role of Hsp90 and small Hsps as molecular chaperones. Trends in Biochemical Sciences 19 205-211.

Johansson L, Båvner A, Thomsen JS, Färnegårdh M-H, Gustafsson J-Å \& Treuter E 2000 The orphan nuclear receptor SHP utilizes conserved LXXLL-related motifs for interactions with ligand-activated estrogen receptors. Molecular and Cellular Biology 20 1124-1133.

Jordan VC 1984 Biochemical pharmacology of antiestrogen action. Pharmacological Reviews 36 245-270.

Jordan VC 1993 A current view of tamoxifen for the treatment and prevention of breast cancer. British Fournal of Pharmacology 110 507-517.

Jordan VC \& Assikis VJ 1995 Endometrial carcinoma and tamoxifen: clearing up a controversy. Clinical Cancer Research 1 467-472.

Krishnan V, Wang X \& Safe S 1994 Estrogen receptor-Sp1 complexes mediate estrogen-induced cathepsin D gene expression in MCF-7 human breast cancer cells. Fournal of Biological Chemistry 269 15912-15917.

Krishnan V, Porter W, Santostefano M Wang X \& Safe S 1995 Molecular mechanism of inhibition of estrogen-induced cathepsin D gene expression by 2,3,7,8-tetrachlorodibenzo$p$-dioxin (TCDD) in MCF-7 cells. Molecular and Cellular Biology 15 6710-6719.

Kumar V, Green S, Staub A \& Chambon P 1986 Localization of the oestradiol-binding and putative DNA binding domains of the human oestrogen receptor. EMBO Fournal $\mathbf{5}$ 2231-2236.

Kumar V, Green S, Stack G, Berry M, Jin J-R \& Chambon P 1987 Functional domains of the human estrogen receptor. Cell 51 941-951.

Langdon SP, Rabiasz GJ, Hirst GL, King RJ, Hawkins RA, Smyth JF \& Miller WR 1995 Expression of the heat shock protein HSP27 in human ovarian cancer. Clinical Cancer Research 1 1603-1609.

Lemon BD \& Freedman LP 1999 Nuclear receptor cofactors as chromatin remodelers. Current Opinions in Genetics \& Development 9 499-504.

Lindquist S \& Craig EA 1988 The heat-shock proteins. Annual Review of Genetics 22 631-677.

Lu Y-F, Sun G, Wang X \& Safe S 1996 Inhibition of prolactin receptor gene expression by 2,3,7,8-tetrachlorodibenzo- $p$ dioxin in MCF-7 human breast cancer cells. Archives of Biochemistry and Biophysics 332 35-40.

MacGregor JI \& Jordan VC 1998 Basic guide to the mechanisms of antiestrogen action. Pharmacological Reviews 50 151-196.

McDonnell DP, Clemm DL, Hermann T, Goldman ME \& Pike JW 1995 Analysis of estrogen receptor function in vitro reveals three distinct classes of antiestrogens. Molecular Endocrinology 9 659-669.

McKenna NJ, Xu J, Nawaz Z, Tsai SY, Tsai MJ \& O’Malley BW 1999 Nuclear receptor coactivators: multiple enzymes, multiple complexes, multiple functions. Fournal of Steroid Biochemistry and Molecular Biology 69 3-12.

Mairesse N, Horman S, Mosselmans R \& Galand P 1996 Antisense inhibition of the $27 \mathrm{kDa}$ heat shock protein production affects growth rate and cytoskeletal organization in MCF-7 cells. Cell Biology International 20 205-212.
Mehlen P, Schulze-Osthoff K \& Arrigo AP 1996 Small stress proteins as novel regulators of apoptosis. Heat shock protein 27 blocks Fas/APO-1- and staurosporineinduced cell death. Fournal of Biological Chemistry 271 16510-16514.

Mehlen P, Mehlen A, Godet J \& Arrigo AP 1997 hsp27 as a switch between differentiation and apoptosis in murine embryonic stem cells. Fournal of Biological Chemistry 272 31657-31665.

Metzger D, Berry M, Ali S \& Chambon P 1995 Effect of antagonists on DNA binding properties of the human estrogen receptor in vitro and in vivo. Molecular Endocrinology 9 579-591.

Moore M, Wang X, Lu YF, Wormke M, Craig A, Gerlach JH, Burghardt R, Barhoumi R \& Safe S 1994 Benzo[a]pyreneresistant MCF-7 human breast cancer cells. A unique aryl hydrocarbon-nonresponsive clone. Fournal of Biological Chemistry 269 11751-11759.

Moretti-Rojas I, Fuqua SA, Montgomery RA \& McGuire WL 1988 A cDNA for the estradiol-regulated 24K protein: control of mRNA levels in MCF-7 cells. Breast Cancer Research and Treatment 11 155-163.

Munoz de Toro MM \& Luque EH 1997 Lack of relationship between the expression of Hsp27 heat shock estrogen receptor-associated protein and estrogen receptor or progesterone receptor status in male breast carcinoma. Fournal of Steroid Biochemistry and Molecular Biology 60 277-284.

Norris JD, Paige LA, Christensen DJ, Chang C-Y, Huacani MR, Fan D, Hamilton PT, Fowlkes DM \& McDonnell DP 1999 Peptide antagonists of the human estrogen receptor. Science 285 744-746.

Oesterreich S, Weng C-N, Qiu M, Hilsenbeck SG, Osborne CK \& Fuqua SAW 1993 The small heat shock protein hsp27 is correlated with growth and drug resistance in human breast cancer cell lines. Cancer Research 53 4443-4448.

Oesterreich S, Hickey E, Weber LA \& Fuqua SA $1996 a$ Basal regulatory promoter elements of the hsp 27 gene in human breast cancer cells. Biochemical and Biophysical Research Communications 222 155-163.

Oesterreich S, Hilsenbeck SG, Ciocca DR, Allred DC, Clark GM, Chamness GC, Osborne CK \& Fuqua SA $1996 b$ The small heat shock protein HSP27 is not an independent prognostic marker in axillary lymph node-negative breast cancer patients. Clinical Cancer Research 2 1199-1206.

Oesterreich S, Lee AV, Sullivan TM, Samuel SK, Davie JR \& Fuqua SA 1997 Novel nuclear matrix protein HET binds to and influences activity of the HSP27 promoter in human breast cancer cell. Fournal of Cellular Biochemistry 67 275-286.

Paech K, Webb P, Kuiper GG, Nilsson S, Gustafsson J, Kushner PJ \& Scanlan TS 1997 Differential ligand activation of estrogen receptors ER $\alpha$ and ER $\beta$ at AP1 sites. Science 277 $1508-1510$.

Paige LA, Christensen DJ, Gron H, Norris JD, Gottlin EB, Padilla KM, Change CY, Ballas LM, Hamilton PT, McDonnell DP \& Fowlkes DM 1999 Estrogen receptor (ER) modulators each induce distinct conformational changes in $\mathrm{ER} \alpha$ and ER $\beta$. PNAS 96 3999-4004.

Parker MG 1993 Action of 'pure' antiestrogens in inhibiting estrogen receptor action. Breast Cancer Research and Treatment 26 131-137.

Porter W \& Safe S 1998 Estrogenic and antiestrogenic compounds. In Molecular Biology Approaches to Toxicology, pp 267-283. Eds A Puga \& KB Wallace. Fairfax, VA: Techbooks.

Porter W, Wang F, Wang W, Duan R \& Safe S 1996 Role of estrogen receptor/Sp1 complexes in estrogen-induced heat 
shock protein 27 gene expression. Molecular Endocrinology 10 1371-1378.

Porter W, Saville B, Hoivik D \& Safe S 1997 Functional synergy between the transcription factor $\mathrm{Sp} 1$ and the estrogen receptor. Molecular Endocrinology 11 1569-1580.

Qin C, Singh P \& Safe S 1999 Transcriptional activation of insulin-like growth factor binding protein 4 by $17 \beta$-estradiol in MCF-7 cells: role of estrogen receptor-Sp1 complexes. Endocrinology 140 2501-2508.

Reese JC \& Katzenellenbogen BS 1991 Differential DNAbinding abilities of estrogen receptor occupied with two classes of antiestrogens - studies using human estrogen receptor overexpressed in mammalian cells. Nucleic Acids Research 19 6595-6602.

Resnick EM, Schreihofer DA, Periasamy A \& Shupnik MA 2000 Truncated estrogen receptor product-1 suppresses estrogen receptor transactivation by dimerization with estrogen receptors $\alpha$ and $\beta$. Fournal of Biological Chemistry $2757158-7166$

Safe S 1995 Modulation of gene expression and endocrine response pathways by 2,3,7,8-tetrachlorodibenzo- $p$-dioxin and related compounds. Pharmacological Therapy 67 247-281.

Safe S 1999 2,3,7,8-Tetrachlorodibenzo-p-dioxin (TCDD) and related environmental antiestrogens: characterization and mechanism of action. In Endocrine Disruptors, pp 187-221. Ed RK Naz. Boca Raton, FL: CRC Press.

Safe S, Qin C \& McDougal A 1999 Development of selective aryl hydrocarbon receptor modulators (SARMs) for treatment of breast cancer. Expert Opinion on Investigational Drugs 8 1385-1396.

Saville B, Wormke M, Wang F, Nguyen T, Enmark E, Kuiper G, Gustafsson J-A \& Safe S 2000 Ligand-, cell- and estrogen receptor subtype $(\alpha / \beta)$-dependent activation at GC-rich (Sp1) promoter elements. Fournal of Biological Chemistry 275 5379-5387.

Smith DF, Whitesell L \& Katsanis E 1998 Molecular chaperones: biology and prospects for pharmacological intervention. Pharmacological Reviews 50 493-514.

Sun G, Porter W \& Safe S 1998 Estrogen-induced retinoic acid receptor $\alpha 1$ gene expression: role of estrogen receptor-Sp1 complex. Molecular Endocrinology 12 882-890.

Swanson HI \& Bradfield CA 1993 The Ah-receptor: genetics, structure and function. Pharmacogenetics 3 213-223.

Tetu B, Lacasse B, Bouchard HL, Lagace R, Huot J \& Landry J 1992 Prognostic influence of HSP-27 expression in malignant fibrous histiocytoma: a clinicopathological and immunohistochemical study. Cancer Research 52 2325-2328.

Tzukerman MT, Esty A, Santiso-Mere D, Danielian P, Parker MG, Stein RG, Pike JW \& McDonnell DP 1994 Human estrogen receptor transactivational capacity is determined by both cellular and promoter context and mediated by two functionally distinct intramolecular regions. Molecular Endocrinology 8 21-30.

Van Den Bemd GJ, Kuiper GG, Pols HA \& van Leeuwen JP 1999 Distinct effects on the conformation of estrogen receptor $\alpha$ and $\beta$ by both the antiestrogens ICI 164,384 and ICI 182,780 leading to opposite effects on receptor stability. Biochemical and Biophysical Research Communications 261 $1-5$.

Vyhlidal C, Samudio I, Kladde M \& Safe S 2000

Transcriptional activation of transforming growth factor $\alpha$ by estradiol: requirement for both a GC-rich site and an estrogen response element half-site. Fournal of Molecular Endocrinology 24 329-338.
Wagstaff MJ, Collaco-Moraes Y, Smith J, de Belleroche JS, Coffin RS \& Latchman DS 1999 Protection of neuronal cells from apoptosis by Hsp27 delivered with a herpes simplex virus-based vector. Fournal of Biological Chemistry 274 5061-5069.

Wakeling AE 1993 The future of new pure antiestrogens in clinical breast cancer. Breast Cancer Research and Treatment 25 1-9.

Wakeling AE \& Bowler J 1988 Novel antioestrogens without partial agonist activity. Fournal of Steroid Biochemistry 31 645-653.

Wakeling AE, Dukes M \& Bowler J 1991 A potent specific pure antioestrogen with clinical potential. Cancer Research $\mathbf{5 1}$ 3867-3873.

Wang F, Hoivik D, Pollenz R \& Safe S 1998 Functional and physical interactions between the estrogen receptor-Sp1 and the nuclear aryl hydrocarbon receptor complexes. Nucleic Acids Research 26 3044-3052.

Wang W, Dong L, Saville B \& Safe S 1999 Transcriptional activation of E2F1 gene expression by $17 \beta$-estradiol in MCF-7 cells is regulated by NF-Y-Sp1/estrogen receptor interactions. Molecular Endocrinology 13 1373-1387.

Webb P, Lopez GN, Uht RM \& Kushner PJ 1995 Tamoxifen activation of the estrogen receptor/AP-1 pathway: potential origin for the cell-specific estrogen-like effects of antiestrogens. Molecular Endocrinology 9 443-456.

Webb P, Nguyen P, Valentine C, Lopez GN, Kwok GR, McInerney E, Katzenellenbogen BS, Enmark E, Gustafsson J-Å, Nilsson S \& Kushner PJ 1999 The estrogen receptor enhances AP-1 activity by two distinct mechanisms with different requirements for receptor transactivation functions. Molecular Endocrinology 13 1672-1685.

Whitlock JP, Jr 1993 Mechanistic aspects of dioxin action. Chemical Research in Toxicology 6 754-763.

Whitlock JP, Okino ST, Dong L, Ko HP, Clarke-Katzenberg R, Ma Q \& Li H 1996 Induction of cytochrome P4501A1: a model for analyzing mammalian gene transcription. FASEB Fournal 10 809-818.

Xie W, Duan R \& Safe S 1999 Estrogen induces adenosine deaminase gene expression in MCF-7 human breast cancer cells: role of estrogen receptor-Sp1 interactions. Endocrinology 140 219-227.

Ying C \& Lin D-H 2000 Estrogen-modulated estrogen receptor pit-1 protein complex formation and prolactin gene activation require novel protein synthesis. Fournal of Biological Chemistry 275 15407-15412.

Yoon K, Pallaroni L, Ramamoorthy K, Gaido K \& Safe S 2000 Ligand structure-dependent differences in activation of estrogen receptor $\alpha$ in human HepG2 liver and U2 osteogenic cancer cell lines. Molecular and Cellular Endocrinology 162 211-220.

Zacharewski T \& Safe S 1998 Antiestrogenic activity of TCDD and related compounds. In Reproductive and Developmental Toxicology, pp 431-448. Ed KS Korach. New York: Marcel Dekker.

Zacharewski TR, Bondy KL, McDonell P \& Wu ZF 1994 Antiestrogenic effects of 2,3,7,8-tetrachlorodibenzo- $p$-dioxin on $17 \beta$-estradiol-induced pS2 expression. Cancer Research 54 $2707-2713$.

Zwijsen RM, Wientjens E, Klompmaker R, van der Sman J, Bernards R \& Michalides RJ 1997 CDK-independent activation of estrogen receptor by cyclin D1. Cell $\mathbf{8 8}$ $405-415$.

REVISED MANUSCRIPT RECEIVED 24 August 2000 